Revista Iberoamericana, Vol. LXXVII, Núms. 236-237, Julio-Diciembre 2011, 919-937

\title{
DEL SIMULACRO A LO REAL: \\ HACIA UN REALISMO DEL SIMULACRO
}

POR

Jesús MONTOYa JuÁREZ

Universidad de Granada

\section{INTRODUCCIÓN}

Si el concepto de simulacro en la teoría de los años ochenta refería a la manera en que se volvía hiperreal la realidad cartesiana en tanto suplantaba viejos modos de percibirla por otros en que estaban implicadas nuevas mediaciones que devenían globales y se superponían efectivamente a la realidad misma, en los años noventa el sensorium simulacional se vuelve un espacio "real” materializándose en lo "virtual". Como ocurre según Foucault con la cárcel que idea Bentham en el siglo xIx en el último tercio del siglo xx, la tecnología de la realidad virtual y el ciberespacio -nos sugieren Poster, Ryan, Zizek, Virilio o Hayles, entre otros- materializa un espacio en el que una parte de la vida de los seres humanos, una parte de su subjetividad, puede desenvolverse. Desde los años noventa el simulacro abandona el territorio de las metáforas que explicaban los cambios en el sensorium y se objetiva en la tecnología de la "segunda edad de los media” (Poster) como Realidad Virtual y ciberespacio. En un momento en el que el viejo theme de la ciencia ficción no es legible como alegoría sino que deviene verdadero principio de mímesis de lo contemporáneo, la desrealización, el simulacro, lo hiperreal, han dado a luz lo virtual. Y los procesos culturales derivados de estos agenciamientos tecnológicos, puestos de relieve en la teoría latinoamericanista, ${ }^{1}$ marcan el contexto desde el que es necesario pensar el panorama narrativo latinoamericano de los últimos años.

En ese panorama pocas obras han recibido de forma simultánea elogios y críticas tan dispares como la del escritor pringlense César Aira (1949). Instituida en una suerte de "marca literaria" (Montaldo), su literatura se inscribe en una tradición que tiene sus hitos en Lautreamont, Arlt, Puig, Lamborghini y Copi. La intervención de Aira en el campo literario no sólo ha proporcionado notoriedad a esa tradición aproximando a sus representantes a través de su particular lectura sino que, además, ha vuelto visibles en el contexto de la narrativa más reciente a escritores muy diferentes que se hallan por

1 Véase los trabajos de Achugar, Richard, Sarlo y Martín-Barbero. 
diversas razones en sintonía con "algo de lo de Aira"² o con algo de esa tradición "a través de lo de Aira". En la "marca-Aira" se conjugan lo metaficcional, la trasgresión de las categorías de lo alto y lo bajo, lo literario y lo masivo, plegándose a una narrativa del silencio que, al mismo tiempo, en un contexto inédito de convivencia de lo literario con otras redes discursivas fruto de la multiplicidad de la información, la massmediación y el espectáculo, se proyecta hacia el afuera de la literatura en un impulso ecfrástico ${ }^{3}$ que al mismo tiempo se quiere realista. Si la crítica ha señalado que la seducción de la “marca-Aira” parece descansar en la negación de un mensaje o de la posibilidad de inferir un sentido en la lectura, planteamiento cuya seducción entronca con la construcción desde los textos de un mito personal entre lo "entre la impersonalidad de lo ya hecho y la singularidad de la firma” (Contreras 31), no es menos cierto que, más allá de la vindicación reiterada de la vanguardia como modelo de su "arte como procedimiento", encontramos que la influencia de la obra de Aira en ciertas estéticas del presente en el Río de la Plata quizás tenga que ver más con el modo en que los textos construyen su realismo a través de esta negación vanguardista de la representación. En buena parte de la narrativa airiana más reciente, podemos afirmar, se construye lo real como un límite de la representación, como un sublime no nostálgico de una experiencia previa o moderna extinguida que, si puede reivindicarse como "realismo", será un realismo del simulacro.

Apoyándonos en el concepto de realidad como un constructo cruzado de los órdenes real, simbólico e imaginario que establece Lacan, podemos decir que la narrativa airiana agrupa sus referencias a un "real" o a una "realidad" al menos en torno a dos niveles: la realidad de partida, lo que está al principio o los fragmentos miméticos que muchas de sus novelas se toman la molestia de construir, y, en segundo lugar, la realidad de llegada o "lo real de la realidad". En palabras de Lacan: "Se podría decir que lo real es lo estrictamente impensable. Esto sería al menos su punto de partida” (2).

El límite que elabora el pensamiento lacaniano puede servirnos para pensar dónde ubican los textos de Aira determinado “real” diferente de la realidad que se postula en las

2 Nos hemos extendido más en las conexiones entre Aira y algunos escritores argentinos como Alberto Laiseca, Sergio Bizzio, Daniel Guebel, Washington Cucurto, Dalia Rosetti o Fabián Casas en una ponencia leída en abril de 2007 en el Seminario Internacional de Narrativa Hispanoamericana Contemporánea de Granada. Una versión reducida de la misma aparece en Entre lo local y lo global: la narrativa latinoamericana en el cambio de siglo (“Aira y los airianos”), de Montoya Juárez y Esteban.

3 Podríamos definir el concepto de écfrasis junto a Murray Krieger "La écfrasis presupone claramente que un arte [...] define su objeto a través de su dependencia del objeto de otro arte -pintura, escultura u otros" ("Ekphrasis [...] clearly presupposes that one art [...] is defining its mission through its dependence on the mission of another art- painting, sculpture or others” [6]), o, ampliando su campo semántico, aunque originalmente fuera predicable de las relaciones del texto con las artes figurativas, junto a Heffernan, a otras artes o formas de reproducción visual; así, podríamos afirmar que la écfrasis es toda representación verbal mediada por la representación visual (“[ekphrasis is] the verbal representation of visual representation” [297]).

\footnotetext{
Revista Iberoamericana, Vol. LXXVII, Núms. 236-237, Julio-Diciembre 2011, $919-937$
ISSN 0034-9631 (Impreso) 
novelas de inicio. Un "real” como punto de destino, para cuya expresión juega un papel primordial la "des-realización" de la realidad simbolizada a través de un entrecomillado verosímil más o menos "realista". Es en este sentido que el cruce de lo visual en la mayoría de las novelas airianas de los noventa puede leerse como una vuelta del relato (Contreras 22-23), pero también como una restitución de lo real que para afirmarse debe liquidar cierta verosimilitud de corte mimético-realista. En resumen: a través de la disolución de la realidad "realista” se accede a otra forma contemporánea de "realismo".

Paradójicamente, en estas fábulas metatextuales es en la sustracción del verosímil y la interferencia de los lenguajes de la tecnología audiovisual posmoderna cuando parece afirmarse en un "verdadero realismo". Una y otra vez en la novelística airiana de los noventa la precipitación en lo massmediático toma la forma de un abandono del verosímil realista previamente construido, como si todo lo escrito previamente fuera, en palabras de Aira, aquello que "da peso al abandono" (“Ars narrativa” 4). En Aira la coagulación imaginaria y la aceleración en el verosímil a partir de un cierto momentobisagra en muchas de sus novelas se tematiza en la figura de la anamorfosis, el medio por el que la realidad -por decirlo en términos airianos- "se hace real".

El debate sobre la cuestión del realismo ha flotado siempre en los estudios referidos a la obra del autor, sea al abordar cuestiones de orden narratológico e identitario ${ }^{4}$ o en aproximaciones comparativas, analizando el papel de la literatura de Aira en relación a su generación o la generación inmediatamente anterior, la de figuras centrales del campo literario argentino como Juan José Saer o Ricardo Piglia (Contreras 22-23), habida cuenta de la omnipresencia del concepto no ya en la obra narrativa, sino en los ensayos de Aira. Pero en ningún caso ha sido abordado en toda su compleja relación con el espectro audiovisual. La paradoja de si una narrativa tan fuertemente metaficcional como la de Aira, hermética y autorreferencial, ${ }^{5}$ pueda leerse como realismo queda en suspenso.

LOS NOVENTA Y LA TELEVISUALIZACIÓN DE LA POLÍTICA

Resulta significativo que esta "televisualización" acompañada de una reflexión alrededor del realismo en la narrativa del escritor pringlense se vuelva particularmente obsesiva desde lo escrito en 1987. Leemos este hecho como un síntoma de una atmósfera nueva en la cultura argentina (Montoya Juárez, “Aira”). Entre el final del gobierno

4 Fernández della Barca, Estrín, Contreras, Breuil y García.

5 Como ha señalado Remón Reillard, la noción de fábula metatextual es particularmente adecuada y también elegida por el propio autor, para comprender el procedimiento airiano del continuo que se establece "entre la novela escrita y el trabajo de escribirla” (Aira, Copi 52-53), que Remón Raillard califica como "[...] un modo de representación paradójica en el que se da una fusión de términos que lógicamente deberían regirse por una relación de causa a efecto. En otras palabras nos hallamos ante el objeto terminado que simultáneamente nos muestra cómo está siendo creado” (143-44).

ISSN 0034-9631 (Impreso) 
radical y el inicio de las políticas neoliberales del nuevo peronismo, con las reformas y privatizaciones del ejecutivo de Menem, se produce en Argentina un inédito boom de las emisiones audiovisuales que da como resultado un proceso de contaminación sin precedentes de la iconosfera (Gubern 133-53) que establece las condiciones para la constitución de lo "espectacular", o de un nuevo sensorium que hemos descrito como "simulacro", que afecta a todos los aspectos de la esfera pública y política del país. Durante este período la televisión en Argentina alcanza una extraordinaria fuerza mito-poética, convirtiéndose en el espacio de más influencia en la transformación de la identidad argentina y del espacio en que se juega el destino de lo político. ${ }^{6}$

Éste es el período -desde la transición democrática, pero sobre todo durante la década menemista-en el que se produce lo que hemos descrito como "televisualización" o -con Contreras- como "caída en lo masivo" de la narrativa de Aira, cuando se hacen particularmente abigarradas y significativas las conexiones de la narrativa airiana con la cultura de masas, no sólo por la parodización de determinados géneros, personajes o imágenes procedentes de la cultura de masas, también por lo indistinto de su selección desjerarquizada de elementos a incluir y su voluntad de hacer funcionar la narrativa como si de una emisión televisiva se tratara. Todo ello dota a sus textos de una textura massmediática que al mismo tiempo determina el modo de presentación en el mercado de una narrativa que funciona y busca distribuirse a sí misma, con la proliferación sobreabundante de novelitas en editoriales de tirada diversa, según una paradójica artesanía que simula la lógica de lo masivo. ${ }^{7}$

Es también el período en el que la obsesión por una afirmación de un realismo como distorsión de un planteamiento realista de inicio en los textos se da con mayor insistencia y radicalidad. Y esto es lo que vamos a tratar de analizar en las páginas siguientes: cómo la tecnología y la gramática de la imagen y los mass media, en este caso la infografía o la fotografía digital, inciden en el verosímil de la narrativa del período a través del análisis de un texto fundamental de Aira: La prueba, escrita en 1989 y publicada en 1992, que ha llegado a ser versionada cinematográficamente ${ }^{8}$ y constituye una referencia fundamental para la joven narrativa en el Río de la Plata.

6 En este sentido cabe leer la televisualización anacrónica de los mitos fundacionales de la nación que Aira elabora en su "trilogía de la liebre” (Montoya Juárez, “Aira”).

7 Véase mis artículos “César Aira, lo básico e la invención” y "Las mil caras de César Aira”.

8 Diego Lerman en Tan de repente (2002), su ópera prima, versiona esta novela, describiendo la errancia juvenil de las tres jóvenes de Flores que efectúan juntas un viaje al interior -inexistente en la novela de Aira-. El film de Lerman conserva un cierto aire de la Nouvelle Vague. La película reproduce la primera parte de La prueba, manteniendo los personajes, buena parte de los diálogos y el efecto de non-sense de la novela, aunque elude su final onírico.

$\begin{array}{lllll}\text { ISSN 0034-9631 (Impreso) } & \text { ISSN 2154-4794 (Electrónico) }\end{array}$ 


\section{DE CÓMO IR MÁS ALLÁ DE LAS EXPLICACIONES}

La anécdota que conforma el argumento de la novela es relativamente simple: Marcia, una adolescente de clase media baja de barrio, tímida, gorda, paseando por el sempiterno Flores de la novelística airiana es asaltada por dos muchachas a las que el narrador se refiere como punks, "Mao" y su amante "Lenin”. La novela se abre con la declaración de Mao de querer “coger” con la protagonista. El grueso de la novela consiste en un diálogo absurdo que tiene lugar por las calles que circundan la Plaza y los establecimientos de ocio y consumo del barrio -en concreto el "Pumper Nic"-, ${ }^{9}$ en el que reiteradamente Marcia se niega a la proposición de Mao. Un diálogo entre mundos opuestos, el de la adolescente convencional y el de las punks, que nace de la reacción de inadecuación entre lo cotidiano, el paseo vespertino por el barrio, y el exabrupto dirigido a Marcia por Mao:

¿Querés coger? ${ }^{10}$

AMarcia la sorpresa le hizo incomprensible la pregunta. Miró a su alrededor sobresaltada para ver de dónde provenía... Aunque no estaba fuera de lugar, y quizás no podía esperarse otra cosa, en ese laberinto de voces y miradas, a la vez transparente, liviano, sin consecuencias, y denso, veloz, algo salvaje. Pero si uno se ponía a esperar algo... (Aira, Prueba 7)

El texto se estructura en dos partes diferenciadas por un cambio violento en el verosímil. Una primera parte, cuyo verosímil narrativo oscila entre el hiperrealismo de la descripción minuciosa de la superficie visual de las calles y las escenas del presente,

9 Cadena de hamburgueserías popular y muy extendida en la ciudad de Buenos Aires en los ochenta y principios de los noventa.

10 En la primera versión de la novela, publicada en Grupo Editor Latinoamericano, el término "coger”, utilizado en toda Latinoamérica en sentido sexual figurado, aparece autocensurado con puntos suspensivos. Cabría preguntarse por la decisión del autor por reformular la pregunta de un modo más literal en las sucesivas ediciones. No tenemos información suficiente para establecer una hipótesis, si bien es cierto que no es el propósito de este trabajo explicar las variantes textuales en la obra de Aira. Lecturas como las de O’Connor vinculan esos puntos suspensivos del inicio con un juego irónico, del no querer decir lo que luego dice -falsa mojigatería que subraya una estética camp-, o, pensamos, con metáforas de la indecibilidad para subrayar ese "límite de lo real” que no se llega a franquear ni siquiera por el narrador de inicio y que sólo será franqueado cuando se atraviese el umbral de la acción, en la escena final del supermercado. No obstante, el abandono de ese recurso en una edición posterior de la novela puede volverlo menos significativo. Es la única variante textual que hemos encontrado en las dos ediciones que hemos contrastado, lo cual sorprende, puesto que parte del procedimiento vindicado por Aira contempla la corrección en lo siguiente, o la no revisión de sus textos. Existe la posibilidad de la traición editorial, Haikus, publicado por Mate, es otra obrita de Aira, inclasificable, nunca reeditada, de la que Aira se queja de haber sido traicionado por su editor, no respetando la estructura que él mismo quiso darle. Así nos lo confiesa en una entrevista de 2004 el propio autor (Montoya Juárez, “César Aira”).

Revista Iberoamericana, Vol. LXXVII, Núms. 236-237, Julio-Diciembre 2011, 919-937 ISSN 0034-9631 (Impreso) 
narra el recorrido físico que hacen los protagonistas por los espacios de la cotidianidad barrial de Flores. Si en un principio la protagonista muestra un cierto rechazo a la proposición y la figura de las dos punks, termina orientando sus esfuerzos en el diálogo hacia la comprensión de las motivaciones de sus acompañantes, su modo de ser, su posición ideológica o su visión del mundo, en un verdadero esfuerzo etnográfico que está buscando reiteradamente conceptos que le permitirían apresar el modo en que se conducen sus interlocutoras y, al mismo tiempo, aislar los preconceptos de los que ella misma parte. En esta primera sección se construye una forma de verosímil realista que acepta ciertos elementos extraños al contrato mimético, por ejemplo, que la voz del autor y sus digresiones teóricas se inmiscuyan sin excesivo problema en el discurso de una adolescente de apenas dieciséis años, como si el narrador no quisiera que los lectores suspendan definitivamente el descreimiento (O’Connor 23-24):

Era verdad, en cierto modo. Salvo que Marcia no creía poder avanzar [...] si no era cambiando de papel, haciendo personajes. De otro modo se metía en callejones sin salida, se precipitaba al abismo, la paralizaba el miedo. En ese momento se le ocurrió que quizás ese miedo era algo que había que mirar de frente, algo que aceptar. Ésa podía ser la lección del nihilismo punk. Pero no lo creía; por un lado, sus dos acompañantes negarían que tuvieran ninguna lección que proponerle; por otro, ellas mismas, disfrazadas como estaban, eran un mentís a esa moral. Aunque no era tan descabellado, dentro del clima de transmutación de todos los valores en el que se movían. (Aira, Prueba 36)

La primera parte, que abarca los dos primeros tercios de la novela, está narrada en una tercera persona por un narrador que mantiene el modo realista, si bien existen algunas diferencias en la presentación de los personajes: frente a Marcia, las dos punks son presentadas como superficies objetivas y sólo son descritas en su modo de actuar, de hablar o desde el punto de vista de Marcia, único personaje que el narrador penetra o adopta.

La segunda parte se inicia con una revelación de un secreto, un secreto que quizá no sea tal y se recoge en apenas las últimas veinte páginas. Mao hace a Marcia una revelación aparentemente tautológica, que no avanza en la explicación del sentido sino que vuelve sobre el principio, a la declaración amorosa: Mao revela a Marcia que, de algún modo, el amor que siente es en realidad la vía de acceso a un "real", un real resistente a toda definición, un real inmediato alejado de la realidad simbolizada o de lo que en la novela se denomina "reino de las explicaciones", un real más real que lo aparentemente real, que es descrito como "un sueño hecho realidad" o con reiterada frecuencia como "lo real de la realidad". La revelación en realidad no parece revelar nada, no dota de contenido o de sentido a los conceptos. En el discurso de Mao ni el "amor", como tampoco "lo real” o "la felicidad" son definidos, continúan herméticos, sin posibilidad de equivalencias. Sólo puesto en funcionamiento -con la acción- el

Revista Iberoamericana, Vol. LXXVII, Núms. 236-237, Julio-Diciembre 2011, 919-937
ISSN 2154-4794 (Electrónico) 
amor cobrará sentido, un sentido que recupera, traicionándolos, motivos de la cultura popular y clichés melodramáticos:

\begin{abstract}
Marcia, no te voy a decir una vez más que estás equivocada porque ya debés saberlo. Ese mundo de explicaciones en que vivís es el error. El amor es la salida del error. [...] Mi amor te ha transformado. Ese mundo tuyo está dentro del mundo real, Marcia. Voy a condescender a explicarte un par de cosas, pero tené en cuenta que me refiero al mundo real, no al de las explicaciones. ¿Qué es lo que te impide contestarme? Dos cosas: lo súbito y que yo sea una chica. De lo súbito no es necesario decir nada; vos creés en el amor a primera vista tanto como yo y como todo el mundo. [...] te escandaliza nuestra brutalidad, pero no se te ha ocurrido pensar que en el fondo sólo hay brutalidad. [...] en las mismas explicaciones que estás buscando, cuando llegan al fin, a la explicación última, ¿qué hay sino una claridad desnuda y horrible? (50)
\end{abstract}

La realidad desplegada en el texto previamente se manifiesta como un conjunto de mundos incluidos, de perspectivas monádicas no composibles mediadas por lo simbólico, que se desvanecen cuando se pone a funcionar "el amor". Y en La prueba es particularmente visible la espacialización de esos mundos en el desplazamiento de las protagonistas por Flores y, más en concreto, a partir de la “trasgresión” (Breuil 179) de diferentes umbrales que conectan los espacios abiertos con los espacios cerrados o interiores como el Pumper Nic o el supermercado. La trasgresión física de cada uno de estos umbrales paralela a la trasgresión lingüística inicial, pone a Marcia en una nueva situación en relación a sus dos acompañantes, debiendo reubicarse ella misma a través del diálogo en una posición sostenida por los atributos de la normalidad y lo previsible, hasta que "la realidad comienza" y las explicaciones no pueden sostenerse. Estos atributos son valorados por vez primera cuando las tres jóvenes entran en el "Pumper":

Por dentro el local de Pumper Nic era una llama de luz blanca, con la calefacción al máximo. Entraron las tres juntas, o no del todo, en una fila irregular, Mao la última. ¿La rodeaban acaso, temían que se escapara? Nada de eso. Entraban como tres amigas, dos de un tipo, una de otro. Marcia se sentía tranquila y casi contenta. Dar por terminada la escena de enfrente le resultaba un alivio, era como si entraran en otra etapa, más normal y previsible. (Prueba 21)

La entrada al local significa también el inicio de un proceso de desidentificación de la protagonista seducida por la extrañeza exótica de las punks, por un simulacro de realidad que se superpone o sustituye provisoriamente a la realidad anterior, porque en todo momento Marcia exhibe sus dudas de que efectivamente las punks sean tales, sugiriendo que en realidad proyectan una pose:

Revista Iberoamericana, Vol. LXXVII, Núms. 236-237, Julio-Diciembre 2011, 919-937
ISSN 2154-4794 (Electrónico) 
¿Qué pensaría ese público ultranormal hecho de jóvenes, mayores y niños que comían hamburguesas y tomaban gaseosas? ¿Se sentirían invadidos, amenazados? No pudo evitar la pueril satisfacción de pensar que la envidiaban por estar con ellas, por tener acceso a su modo de ser y pensar, tan esotérico. Quizás pensarían que eran amigas de la infancia: unas habían tomado un camino en la vida, ella otro, y se reunían para intercambiar experiencias. O quizás pensarían (era más lógico, dentro de todo) que ella también era una punk, sólo que vestida y peinada de modo convencional. Apuró el paso para ponerse a la altura de las otras, no fuera que alguien se confundiera y creyera que sólo por casualidad habían entrado juntas” (22) [...] "Lo lógico sería pensar que el efecto se agotaría a la larga; nadie es una caja perpetua de sorpresas, y a pesar de la extrañeza de estos dos ejemplares, bien podía adivinar debajo de ellas un fondo muy escaso, la vulgaridad de unas chicas extraviadas representando un papel. [...] Pero también podía pensar lo contrario [...] quizás el mundo, cuando se transforma una vez, ya no puede dejar de cambiar. (27-28)

Aunque el "amor-real” irrumpe en la novela como "lo súbito", lo "inmediato", lo que no necesita de explicaciones para darse a conocer, sólo puede expresarse a través de "un rodeo", un lenguaje, el de "la prueba de amor". Paradójicamente, de igual manera que Mao rechaza durante toda la novela ingresar al "mundo de las explicaciones”, en el que la quiere ubicar Marcia, pero no puede hacer otra cosa que "explicar" -desplegarsu mundo a partir de un "rodeo" o un "relato" -(Mao a Marcia) "Voy a condescender a explicarte un par de cosas" (50)- el acceso a "lo real de la realidad" acaba sugiriéndose a través del relato de un espectacular asalto al supermercado Disco que se salda con la destrucción del local y la muerte de numerosos consumidores. Pese a todo la legibilidad no se pierde, como ocurre en ciertos fragmentos de la narrativa vanguardista en que se obtura la comunicación narrativa, como en ciertos textos de Osvaldo Lamborghini o en la propia novela iniciática de Aira, Moreira, sino que se acelera, con una diferencia ostensible: ahora, la sustitución violenta del verosímil introduce la exposición del mundo bajo un tipo deécfrasis que podríamos denominar massmediática. Los cuerpos, los objetos, los mismos protagonistas adoptan una textura cinemática o fotográfica, una densidad de imágenes delirantes en las que se materializa una violencia visual expresionista que se ha comparado con la de cierto cine hollywoodense posmoderno -como el film Pulp Fiction (1994), de Quentin Tarantino (Santos 208)-, y en ese deslizamiento hacia lo visual, remarcado por ciertas referencias metatextuales al lenguaje fotográfico y a la visualidad massmediática, se insertan las vindicaciones de la textualidad de hallarnos ante una "captura" aproximada de lo real.

Decimos que se trata de una "captura" aproximada porque, pese a todo, el episodio sigue necesariamente ciñéndose al "rodeo" de la "acción”, moviéndose por tanto en el borde interior del "mundo de las explicaciones". No obstante, en las referencias al marco o a la exterioridad material de la imagen del fragmento final de la novela podemos leer

\footnotetext{
Revista Iberoamericana, Vol. LXXVII, Núms. 236-237, Julio-Diciembre 2011, 919-937
ISSN 2154-4794 (Electrónico)
} 
un recurso típico de la representación ecfrástica ${ }^{11}$ (Pineda 257), o en la explicitación de una temporalidad retardada simultánea a la velocidad hiperacelerada, alusiones propias de la tecnología del vídeo (González Requena, Discurso 156; Sarlo 63):

Pero su advertencia del principio reverberaba ahora en la conciencia colectiva de los rehenes: si todo esto se hacía por amor, faltaba algo, faltaba más horror. El amor siempre podía más. Y en respuesta a este pedido Lenin tomó una iniciativa escalofriante. [...] se oyó el paso estrepitoso de un carrito lanzado de un extremo al otro del corredor del fondo, como un misil. Los que estaban cerca pudieron ver que iba cargado hasta el tope con botellas de champagne, coronadas por media docena de bidones de nafta, y con una aureola de fuego azul [... ] chocó contra la punta de la góndola de gaseosas. La explosión fue inaudita, la onda expansiva un oleaje espeso de polvo de vidrio verde y alcohol inflamado. La onda produjo además el estallido en veloz sucesión de un millar de botellas de gaseosa. [...] Los movimientos de Mao sobre las cajas se habían hecho de una lentitud sobrenatural. (Aira, Prueba 66-67)

La forma bajo la que ingresa la écfrasis en la presentación de las escenas visuales que se suceden en el supermercado contribuye, no a traducir la gramática visual en recursos narrativos, sino a hacer ingresar las imágenes como objetos extraños a la textualidad ("resident aliens") (Mitchell 157). El narrador marca la textura visual de la violencia desplegada en el fragmento, aislando las imágenes para que éstas no queden integradas completamente en lo textual y, resulten, de alguna manera, marcados los límites de ambos lenguajes en su misma intersección.

Josefina Ludmer ha señalado a propósito de la opción final por la violencia en la novela de Aira que ésta es expresión de la "violencia gratuita"12 de los años noventa (Ludmer 366-67). Lidia Santos replica que esta violencia "no es gratuita" sino que expresa la nueva configuración social implantada por el neoliberalismo": Mao y Lenin, cuyos apodos se vinculan a las dos alternativas más seguidas en el marxismo de los años sesenta, representadas por las "guerrillas" (Mao) y los "partidos comunistas"

${ }^{11}$ Con frecuencia, como ocurre en la novela, en la representación ecfrástica el marco del cuadro, del fotograma o la fotografía se citan expresamente para marcar la densidad artificial de lo representado o su calidad de objeto visual.

12 Lipovetsky señala a propósito de la violencia en las sociedades posmodernas una cierta gratuidad vinculada al espectáculo. "[...] esa criminalidad hard, sin proyecto, sin ambición, sin imaginario. El proceso de personalización que aspira a aumentar la responsabilidad de los individuos favorece de hecho los comportamientos aberrantes, inestables, indiferentes de algún modo al principio de realidad, como tales en consonancia con el narcisismo dominante y su correlato, lo real transformado en espectáculo irreal, en un escaparate sin espesor [...] lejos de ser antinómico con el orden cool y narcisista, es su expresión exasperada” (Lipovetsky 209).

Revista Iberoamericana, Vol. LXXVII, Núms. 236-237, Julio-Diciembre 2011, 919-937 ISSN 0034-9631 (Impreso) 
(Lenin), atacan a los consumidores ${ }^{13}$ (Ludmer 366-67; Santos 209). Más allá de estas plausibles lecturas, pensamos que la violencia forma parte de la retórica del realismo que construye la novela a partir de la revelación como momento bisagra o anamorfosis que transforma el verosímil de la novela. La violencia es el complemento necesario del ingreso del lenguaje visual.

En el instante en que tiene lugar la revelación de Mao, Marcia perciberepentinamente la belleza del objeto extraño en su mundo de clase media-la muchacha punk-. Percepción que reenvía a la lectura metaficcional o metanarrativa que vuelve a remitir en el caso de Aira a la pregunta por la calidad artística o el valor literario. Si Marcia, según se insinúa en el texto, concibe a los seres humanos en lo relativo al rubro del amor como estereotipos, es decir, como receptáculos o representaciones de "tipos generales"14 (Prueba 33), la radical diferencia en la repentina extrañeza de la visión de Mao es que su belleza: "no era un efecto. No era el tipo de belleza que se descubría a la corta o a la larga, por el hábito o el amor o por las dos cosas juntas, no era la belleza que se veía por la lente de la subjetividad o el tiempo". Se trata de una belleza "objetiva” una "belleza real” (52), sublime, que no resiste las comparaciones: "Entre sus compañeras de colegio había varias que podían jactarse de bellezas sin falla. En comparación con Mao, eran algo así como ilusiones que caían ante lo real” (52).

La perspectiva abierta por "la revelación" no sólo posibilita el reconocimiento de la belleza en Mao, también de la diferencia o "lo distinto" en Lenin:

Lenin [...] era distinta. Tan distinta que hacía prensar en una clase de belleza que pudiera apreciarse en otra civilización. [...] en ella había un descubrimiento latente, que para Marcia se hizo real en ese momento: lo novelesco. [...] se revelaban como las dos caras de un mismo asunto. La belleza y lo distinto estallaban en la noche, y la transformación que producían no era, como las anteriores que había creído percibir

${ }^{13}$ No obstante, aunque en líneas generales coincidimos con los vínculos entre violencia y mercado que la crítica ha leído en La prueba, diferimos de la lectura que hace Lidia Santos al señalar que ambos personajes femeninos, las punks, se construyen como consumidoras ellas mismas -“[...] ellas también son consumidoras, hecho que el narrador resalta al citar los programas de televisión que miran o el tipo de rock que compran" (Santos 209)-. A diferencia del tratamiento del consumo cultural que operan las novelas de Manuel Puig, en La prueba no hemos encontrado ninguna referencia al tipo de rock que estas punks compran o a los programas de televisión que miran. Si bien es cierto que existen referencias a un cierto reconocimiento por parte de las dos punks de la existencia de grupos como The Cure, no hay reconocimiento alguno de haber escuchado o leído nada vinculado con el grupo o su solista, no hay apología de ningún grupo, menos haber comprado nada relacionado con ello, antes al contrario, es Marcia, la adolescente virgen aparentemente convencional y de clase media, la que sugiere ciertos criterios de consumo para definir o clasificar a las punks como tales.

14 "Marcia era típicamente joven en tanto no concebía el amor sino como una cuestión de tipos generales; uno se enamoraba de un conjunto de características que se reunían en un individuo, y también podrían reunirse en otro. Sólo había que encontrar al que las tuviera. [...] porque el amor puede estar en cualquier parte, en todas; el mundo entero es amor para ellos” (33).

Revista Iberoamericana, Vol. LXXVII, Núms. 236-237, Julio-Diciembre 2011, 919-937 ISSN 0034-9631 (Impreso) 
(ésta las cambiaba de naturaleza), la vuelta de página a una nueva versión del mundo, sino la transformación del mundo en mundo. Era la cima de la extrañeza, y no creyó que se pudiera ir más lejos. (52-53)

La pregunta por cómo unas punks a las claras construidas como estereotipos se pueden erigir como seres reales se conecta con otra de mayor alcance en la obra de Aira: ¿Cómo lo que está al borde de la desagregación, cómo el fraude puede ser transmutado en verdad o en algo frente a lo que no sea necesario pensar en términos de verdad o falsedad? Es en este sentido que la elaboración del simulacro posmoderno en Aira trabaja sobre el estereotipo para transformarlo en realidad, ${ }^{15}$ o para reconocerse como única posibilidad de seguir escribiendo más allá del fin, del límite, del simulacro. Sobre esta cuestión debemos regresar, para pensar el costado político de esta explicitación y transgresión de los límites de la representación, para afirmar sin embargo un realismo. ${ }^{16}$ Si la literatura de Aira se distingue por lo que Sandra Contreras ha denominado las vueltas del relato- vuelta al relato después de los experimentos antinarrativos de la neovanguardia sesentista, frente al modelo ejemplarizado por las narraciones de Piglia o Saer, vuelta o forzamiento también del relato en las novelas airianas (Contreras 22) -quizás una metáfora válida para describir cómo trabajan los textos la cuestión del abandono del relato sin llegar definitivamente a abandonarlo pueda ser la de la "media vuelta” (Prieto 182):

[...] la vuelta al revés del relato, tal como se vuelve del revés un guante, dejando a la vista su forro interior, obsceno e informe. Aunque casi sería más justo hablar de la “media vuelta” del relato: como un guante a medio volver, que no se sabe bien de qué lado va, si del lado de la fábula o del envés de lo real. O, mejor aún, como un guante-globo a medio inflar, que lo mismo se hincha hasta un máximo de invención que se deshincha de golpe, con el resoplido irrisorio de brusca caída de la ficción en lo real. (Prieto 182)

15 En “invención”, en palabras de Contreras, cuyo análisis de La prueba se mueve en el espacio del análisis metaficcional o metaartístico. Pero, ¿no es posible en esta vuelta a la imagen de los estereotipos, pensar implicaciones vinculadas al problema de lo real, el realismo y la representación?

16 El texto de Contreras -reflexionando sobre los estereotipos de la tradición decimonónica que se trabajan en La liebre- deja insinuada una interesante pregunta sobre la que deberemos volver más adelante, la de si toda vez que la narrativa de Aira por la vía de la deconstrucción de los estereotipos o su subrayado hasta la ostensividad camp más obscena no está en realidad potenciándolos, y si esa potenciación como aceleración del verosímil no es una vía por la cual "la literatura salta a otro dominio que el de la representación” (88). La solución de Contreras radica en pensar la narrativa de Aira alrededor de las categorías de invención y afirmación, posicionando a Aira en un altomodernismo que pervive en el contexto contemporáneo de simulacro, moviéndose en el territorio de la reflexión por la periodización artística. Este trabajo busca poner en relación tecnología, mass media y realismo en la narrativa de Aira para preguntarse, ¿puede haber un realismo más allá de la representación? Pensamos que este aspecto de la narrativa airiana debe pensarse todavía más.

Revista Iberoamericana, Vol. LXXVII, Núms. 236-237, Julio-Diciembre 2011, 919-937 ISSN 0034-9631 (Impreso) 
Si en la lectura de Prieto esta "media vuelta” del relato supone tanto una reacción contra las vanguardias como un modo renovado de vanguardia que recupera ciertas técnicas y muestra similaridades con la narrativa de, por ejemplo, Macedonio Fernández, también puede ser válida para pensar el modo en que coexisten en las novelas hermetismo y reproducción de una experiencia contemporánea de lo real. La presentación del simulacro, del límite de la representación, dada media vuelta, escribe en su envés un deseo utópico de real, auténtico mitologema de esta narrativa.

La crítica ha puesto de relieve cómo la narración, que proyecta una literalización de numerosos clichés románticos y telenovelescos que podrían resumirse en el axioma "la fuerza del amor" (Contreras 150), se hibrida con otros géneros, el de la ficción massmediática de los films de acción, el fanzine o el manga. Es evidente que la voz narrativa de La prueba es una voz asimilable a una cierta tradición “camp-queer”, ${ }^{17}$ que puede ponerse en relación con el proyecto escriturario que el autor manifiesta en ciertos textos en los que lo híbrido y lo andrógino se rescatan en tanto ofrecen la posibilidad de materializar los opuestos:

Si uno se decide por la literatura es con ese fin: salir de una lógica de exclusión de los contrarios que califica de falso a uno solo de los miembros del par. No para hacerlos falsos o verdaderos a los dos, sino para ponerlos en una teoría falsa que hace irrelevante la clasificación. Por eso debemos hacer teorías. [...] ¿ Por qué empezar entonces? Por nada. Por una especie de locura benévola al alcance de todos; por pasar el rato. Porque mientras tanto uno está viviendo y debe ocuparse de algo. Esa es la parte de realismo, la única parte de realismo, que tiene nuestro oficio: se hacen teorías con la vida (o viceversa) [...] (Aira, Nouvelles impressions 43)

Esa lógica de las transformaciones es sugerida como coexistencia de opuestos en una teoría falsa en cuyos términos, sin embargo, sea imposible refutar su "verdad” por ser improcedente preguntarnos por la relevancia de tal concepto. Lo necesario, por tanto, es, una vez más, la “creencia en proceso”:

Debo responder con una teoría [...] para concentrarlo en mí (el interés), para volverlo tema y espectáculo. Después de todo, ¿para qué componen sistemas los filósofos? Para poder hablar en sus propios términos, para redefinir todo su vocabulario como una lengua extranjera y no poder ser refutados. Lo mismo hace un escritor, tomando a la filosofía como modelo y dándole a la filosofía esta función de modelo. (Aira, Nouvelles impressions 52)

\footnotetext{
17 "I again invoke Ovid, Sterne and Carrol to remind us that pre-gay and non-homosexual voices in the tradition [...] it is good to recall that the term queer was invented to include sexual transgresiveness that ignore the false binary between heterosexual and homosexual. Aira's voice may not be gay, but it is queer" (O’Connor 24). Revista Iberoamericana, Vol. LXXVII, Núms. 236-237, Julio-Diciembre 2011, $919-937$
ISSN 2154-4794 (Electrónico)
} 
Pero si rastreamos el diálogo que muchos textos de Aira desde los años noventa establecen con las escenas del presente que se eligen como material para ese proyecto, podemos advertir cómo el juego de las transformaciones que se define como verdadera realidad, como un progresivo cambio de atmósfera que en el texto se sugiere por contacto con la "otredad" representada por las "falsas punks", encontramos la explicitación de un límite en la representación y la simultánea apuesta, desde el horizonte del simulacro massmediático, por la explicitación de una cierta realidad. Las novelas de Aira sugieren un "real" a partir de la vuelta imagen de los personajes y las acciones que despliegan. En La prueba se expresa el deseo de fugarse de la "lógica de las explicaciones", del rodeo lingüístico o verbal, en pos de una "expresión fotográfica” o "televisiva” (Montoya Juárez, "Mil caras”, "Ni apocalípticos”) que simultáneamente visibilice el delirio-propio de las imágenes electrónicas (Deleuze)- al tiempo que apele a un "radical fotográfico" (González Requena, "Imagen” 126), a un "punctum" (Barthes 65), expresado por contacto, por contigüidad de lo visual con la materialidad de lo fotografiado, inclusive aunque el cuerpo de lo fotografiado no exista. $\mathrm{Si}$, por un lado, la escena de la prueba funciona como estereotipo, la literalización del axioma melodramático "el amor lo puede todo", a medida que la realidad deviene imagen, la prueba se convierte en "figura de amor" (Contreras), "circunscrita (como un signo) y memorable (como una imagen o un cuento)" (Barthes citado en Contreras 153). El simulacro que se tematiza en los textos airianos, ${ }^{18}$ antes que darse en función de la descriptio de una des-realización de la realidad o sustracción de la experiencia conducente al silencio propia de las formas escriturarias en la senda de la neovanguardia, es, en textos como éste, la exploración de un contexto y un archivo como puntos de partida para un nuevo realismo, que Luz Horne a propósito de Un sueño realizado ha calificado, siguiendo a Pierce, como indicial (113), y que he cifrado en un impulso ecfrástico que acompaña las digresiones teóricas en torno a la noción de la transformación continua, ${ }^{19}$ que se viene sugiriendo desde el principio de la novela.

La declaración violenta de Mao inicia una ruta por lo imprevisible que excede todas las consideraciones articuladas por Marcia y acaba, finalmente, por degenerar en catástrofe, por literalizarse, volviéndose, de alguna manera, "real”. Esta catástrofe visual introduce una lógica onírica que disuelve la coherencia previa de la representación realista en una acumulación de imágenes y formas que se suceden vertiginosamente, como en el género massmediático posmoderno del videoclip. La verdadera realidad comienza cuando se termina la oscilación entre la explicación y las transformaciones -cuando

${ }^{18}$ Incluso cuando se trata de ficciones del procedimiento en que trabaja sobre las posibilidades creativas y artísticas de los diferentes media produciendo cada una de ellas un "simulacro del simulacro" (Aira, Trompeta 127). En Aira hay siempre una obsesiva preocupación por el realismo, por referir a lo exterior a la literatura a sabiendas de que todo es simulacro.

19 Véase mis artículos "Las mil caras de César Aira” y “Aira y los airianos”.

ISSN 0034-9631 (Impreso) 
todo toma la lógica de una gran transformación- en el instante en que da comienzo verdaderamente "la prueba". Es el momento en el que las tres muchachas se adentran en el supermercado, ${ }^{20}$ un nuevo espacio cerrado al que se accede atravesando un umbral:

Cuando entró... no exactamente cuando entró, sino cuando miró atrás y vio lo que hacía Lenin al entrar... fue como si comenzara un sueño. Y al mismo tiempo como si comenzara la realidad. Lenin había sacado del bolsillo, o quizás entre las cosas metálicas que le colgaban del cuello, un grueso candado de hierro negro; cerraba la puerta de vidrio, corría el pasador y le ponía el candado, que al cerrarse hizo un clac que la sobresaltó. Fue como si el candado se hubiera cerrado sobre su corazón, literalmente. Más todavía, fue como si su corazón fuera el candado de hierro negro algo herrumbrado, pero funcionando a la perfección, demasiado bien en realidad. Porque la maniobra había tenido algo de irreversible (un candado, cuando se cierra, parece como si nunca más fuera a abrirse, como si la llave estuviera extraviada desde ya) lo que sumado a lo imprevisto, a la sorpresa, la volvía un sueño hecho realidad. (55)

Bajo las luces fluorescentes que iluminan el supermercado, espacio simbólico por excelencia de la sociedad de consumo (Breuil; Santos), se "prolongan” y "amplifican” los procesos de revelación de la violencia a través de una atmósfera que es al mismo tiempo “desrealizante” "hiperrealizante”(Breuil 176).Atmósfera que hemos vinculado al recurso de la écfrasis -podríamos decir-, écfrasis de la fotografía digital o de las “imágenes infográficas” (Gubern 147). La infografía o la animación por ordenador permiten la manipulación digital de las imágenes fotográficas, haciendo ingresar en éstas lo delirante, la invasión de lo imaginario y la seducción sobre lo real. El realismo de la infografía admite la convención del simulacro como punto de partida, introduce la categoría de la "presentatividad" frente a lo "representativo" (Gubern 147). Estas dos características del lenguaje fotográfico contemporáneo, la contigüidad o el punctum barthesiano, y lo delirante intensificado por la manipulación infográfica, se tematizan en la novela, bien a través de metáforas o adjetivación proveniente del lenguaje fotográfico o massmediático, bien, simplemente, mediante el señalamiento de la superposición de velocidades superpuestas, la aceleración absoluta de lo "súbito", y la inmovilidad fotográfica de la "revelación”:21

${ }^{20}$ No podemos obviar que la escena del atraco y violencia exacerbada traduce como imagen una violencia cotidiana en el período en que se escribe La prueba, 1989: hiperinflación, y saqueos a supermercados a cargo de sectores desfavorecidos para aprovisionarse de mercancías y alimentos se convierten en noticia cotidiana. La exposición espectacular del fragmento -con sus hipérboles expresionistas- no deja de ser, en realidad, la traducción en imagen de otra imagen, pues los acontecimientos que inspiran el relato son percibidos a través de la mediación televisiva. $\mathrm{Y}$ en ese sentido, la transcripción conserva un cierto realismo evanescente, propio del contexto posmoderno.

${ }^{21}$ Como hemos estudiado en otro trabajo (Realidad) sobre Moreira, primera novela de Aira, la cuestión relativa a las perspectivas “acelerada” y "retrasada” (Paz 148), habría de ponerse en relación con la

Revista Iberoamericana, Vol. LXXVII, Núms. 236-237, Julio-Diciembre 2011, 919-937 ISSN 0034-9631 (Impreso) 
Cuando la atacante se alzó, como una moderna Salomé de negro, sostenía con las dos manos la cabeza de la señora. El espectáculo había atraído la atención general. El clamor se multiplicó, y lo que surgía de él, más que los ¡Asesina! ¡Bestia!, etcétera eran los ¡No mires! [...] era la segunda parte de lo soñado: el miedo a soñar. O a recordar, que es lo mismo [...] Mao [...] lanzó la cabeza como una pelota hacia los que gritaban [...] La atmósfera se había enrarecido. El calor del fuego estaba cargado de olores asfixiantes. Toda la materia comestible y bebible del supermercado se transmitía al aire. [...] los envases de solventes, ceras, lustres, amoníacos, estallaban con hedores irrespirables. Las masas cautivas presionaban por alejarse y pasaban unos por encima de las cabezas de los otros [...] en pleno sálvese quien pueda. [...] Góndolas enteras empezaban a derrumbarse sobre la gente. Y la cabeza de la señora seguía en el aire, no porque se hubiera detenido en un milagro de levitación post mortem, sino porque había pasado muy poco tiempo. (68)

Las descripciones ecfrásticas de estas escenas oníricas introducidas junto aun esfuerzo de verosimilización realista rozan el extremo del delirio. Apesar de la impresión de Marcia que nos entrega el narrador -“no se podía ir más allá” (55)- el relato sigue escribiendo tras el fin las transformaciones hasta lo "indiferente" de una violencia extremada que logra su objetivo en el contexto monádico en que tiene lugar, el supermercado. Las transformaciones visuales buscan concitar el delirio y lo real provenientes del lenguaje otro de la fotografía de la era digital (Laddaga 15) o lo massmediático, bajo la forma de una "utopía” o "esperanza ecfrástica” ("ekphrastic hope” [Mitchell 158]), para tematizar, al término de la novela, una expulsión del verosímil realista en pos de un verosímil que se quiere ahora "real”, en un continuo al más allá de la escritura. Nótese en la cita siguiente las referencias al marco en un deseo de volver imagen la escena narrada y conectar el texto con el discurso otro de la representación pictórica o fotográfica:

figura de la anamorfosis de inspiración leibniziana que supone un rasgo sustantivo en esta narrativa, anamorfosis que tiene un carácter eminentemente dual: "[...] la imagen nace de su propia desfiguración, señalando a su paso el carácter doble que la sustenta: es una representación que esconde el objeto mismo que representa” (García 98). Es en este sentido que podemos entender la hiperbolización o el gigantismo y la miniaturización de los tamaños en Aira cuyos ejemplos son legión en sus novelas: la discoteca miniaturizada en Yo era una chica moderna o el aumento y reducción del tamaño del gigante Chin Fu en La guerra de los gimnasios, el camión-planeta-mónada del Chiquito, la Virgen de Los misterios de Rosario, o la perspectiva que disminuye al gaucho que se aproxima a la pulpería en Moreira. La velocidad es, según Virilio, la categoría sobre la cual se apoya la visión, "la velocidad permite ver" (Virilio 23-24). Velocidad y percepción están íntimamente ligadas en La prueba en un sentido idéntico al que lo están en Un sueño realizado, Las noches de Flores o La villa. Nos parece que frente a las velocidades en que se mueven los personajes que pueblan el supermercado, las punks suponen velocidades alternativas hiperaceleración y estatismo- a la velocidad del mercado pudiéndose leer como alegoría de la necesidad de hallar una velocidad particular de la literatura en su contexto actual, el del mercado-espectáculo finisecular. Sobre las relaciones entre mercado, realismo y velocidad en la literatura contemporánea pueden leerse los excelentes trabajos de Daniel Noemí.

Revista Iberoamericana, Vol. LXXVII, Núms. 236-237, Julio-Diciembre 2011, 919-937 ISSN 0034-9631 (Impreso) 


\begin{abstract}
Una mujer, por ejemplo, un ama de casa del barrio [...] se fundía en su lugar a la vista de sus congéneres que no le prestaban atención. El fuego se había apoderado de la fibra viscosa de su tapado matelassé. La señora se hacía monstruo, pero monstruo bayadera, con una voluptuosidad que durante toda la vida se le había escapado: sus miembros se alargaban, una mano al extremo de un brazo de tres metros reptaba por el suelo, una pierna se enroscaba una y otra vez, innumerable como una cobra... Y estaba cantando, sin abrir la boca, con un registro que en comparación habría hecho parecer flatulento y abotagado al de María Callas, sin contar con que el canto se enriquecía en ella con unas risas y jadeos y unas danzas no humanas... Se hacía animal, pero todos los animales al mismo tiempo, animal espectáculo con los barrotes de la jaula saliéndole como espinas de cada repliegue del cuerpo, animal selva cargado de orquídeas. [...] Un arcoiris torrencial la recorría, era roja, azul, blanca de nieve, verde, un verde profundo, sombrío... Se hacía vegetal, piedra, piedra que se entrechocaba, mar, pulpo autómata... Murmuraba, actuaba (Rebeca, una mujer inolvidable), declamaba y era mimo a la vez, era un auto, planeta, envoltura crujiente de caramelo, frase activa y pasiva en japonés... Y al mismo tiempo era sólo una mirada, una pequeña insistencia. Porque otro tanto podía pasar con cualquiera; y de hecho pasaba, ella era apenas un caso entre cientos, un cuadro en una exposición. (69-70)
\end{abstract}

NOTAS PARA UN REALISMO DEL SIMULACRO

Como hemos tratado de señalar a propósito de La prueba, la écfrasis intermedial en la narrativa airiana del período con frecuencia juega un papel como recurso para complejas operaciones y manipulaciones del código realista, y no simplemente resulta funcional a una declarada aspiración de partida de la praxis narrativa de Aira-Duchamp o Godard como modelos para su arte-, o como un tema recurrente de sus novelas. La televisualización y la écfrasis de las representaciones propias de las tecnologías de la segunda edad de los media constituyen las marcas, especialmente desde fines de los ochenta, de un realismo formalmente experimental o un a todas luces construido “realismo del simulacro” (Montoya Juárez, Realismos 193). Así, massmediación y metaironía juegan un papel clave en la elaboración de una retórica de la "literatura mala" en la narrativa de Aira: vanguardista en el gesto y realista en su impulso ecfrástico y su reflexión teórica-realismo del simulacro-toda vez que la realidad ha devenido simulacro y el simulacro, más allá de toda nostalgia de una experiencia previa o moderna, es la vía de acceso a la representación.

$\begin{array}{lllll}\text { ISSN 0034-9631 (Impreso) } & \text { ISSN 2154-4794 (Electrónico) }\end{array}$ 
BiBLIOGRAFÍA

Achugar, Hugo. La Biblioteca en ruinas: reflexiones culturales desde la periferia. Montevideo: Trilce, 1994.

Aira, César. "Ars narrativa”. Comunicación leída en la Segunda Bienal de Literatura Mariano Picón Salas, en Mérida, Venezuela, septiembre de 1993. Copi. Rosario: Beatriz Viterbo, 1991. Haikus. Buenos Aires: Mate, 2000. La guerra de los gimnasios. Buenos Aires: Emecé, 1993. El llanto. Rosario: Beatriz Viterbo, 1992. La mendiga. Buenos Aires: Mondadori, 1998. Los misterios de Rosario. Buenos Aires: Emecé, 1994. Moreira. Buenos Aires: Achával, 1975. Las noches de flores. Barcelona: Mondadori, 2004. Nouvelles Impressions du Petit Maroc. Saint-Nazaire: MEET, 1991.

La prueba. México: Era, 2002.

La villa. Buenos Aires: Emecé, 2001.

Un sueño realizado. Buenos Aires: Alfaguara, 2001.

Yo era una chica moderna. Buenos Aires: Interzona, 2004.

Barthes, Roland. La cámara lúcida, nota sobre la fotografía. Barcelona: Paidós, 1997.

Baudrillard, J. El otro por sí mismo. Barcelona: Anagrama, 1994.

Breuil, Cristina. Poétique de la ville dans l'oeuvre de César Aira. Tesis de doctorado. L’Université stendhal-Grenoble 3. Dir. Michel Lafon. 2003.

Contreras, Sandra. Las vueltas de César Aira. Rosario: Beatriz Viterbo, 2002.

Estrín, Laura. César Aira: el realismo y sus extremos. Buenos Aires: Del Valle, 1999.

Fernández della Barca, Nancy. Narraciones viajeras: César Aira y Juan José Saer. Buenos Aires: Biblos, 2000.

García, Mariano. Degeneraciones textuales, los géneros en la obra de César Aira. Rosario: Beatriz Viterbo, 2006.

González Requena. El discurso televisivo: espectáculo de la posmodernidad. Madrid: Cátedra, 1988.

“La imagen: lo semiótico, lo real, lo imaginario". Sociocriticism XII/1-2 (1998): 117-37.

Gubern, Román. Del bisonte a la realidad virtual: la escena y el laberinto. Barcelona: Anagrama, 2007.

Hayles, Katherine. How We Became Posthuman: Virtual Bodies in Cybernetics, Literature and Informatics. Chicago: U of Chicago P, 1999.

Heffernan, James. “Ekphrasis and Representation”. New Literary History 22/2 (1991): 197-316.

Revista Iberoamericana, Vol. LXXVII, Núms. 236-237, Julio-Diciembre 2011, 919-937 ISSN 0034-9631 (Impreso) 
Horne, Luz. Hacia un nuevo realismo: Caio Fernando Abreu, César Aira, Sergio Chejfec y Joâo Gilberto Noll. Tesis de doctorado. Yale University. Josefina Ludmer, dir. Ann Arbor: ProQuest, 2005.

Krieger, Murray. Ekphrasis: The Ilusion of the Natural Sign. Baltimore: John Hopkins UP, 1992.

Lacan, Jaques. Seminario 22. RSI, versión electrónica de la Escuela Freudiana de Buenos Aires. Buenos Aires: Biblioteca de la EFBA, 1999. < http://es.scribd.com/ doc/7001323/LACAN-Seminario-22-Clase1PDF>. 15 abril 2011.

Lipovetsky, Gilles. La era del vacío: ensayos sobre el individualismo contemporáneo. Barcelona: Anagrama, 1986.

Ludmer, Josefina. El cuerpo del delito, un manual. Buenos Aires: Perfil, 1999.

Martín-Barbero, Jesús. De los medios a las mediaciones. Comunicación, cultura y hegemonía. Santafé de Bogotá: Convenio Andrés Bello-Gustavo Gili, 2003.

“Nuevos regímenes de visualidad y des-centramientos culturales”. Reescrituras. Texto y teoría: estudios culturales 33. L. Rodríguez-Carranza y M. Nagle, eds. Amsterdam: Rodopi, 2004. 19-40.

Mitchell, W.J.Thomas. Picture Theory. Chicago: U of Chicago P, 1994.

Montaldo, Graciela. "Un caso para el olvido: estéticas bizarras en la Argentina”. El Matadero: segunda época, $\mathrm{n}^{\circ}$ 3. Buenos Aires: Corregidor, 2005. 37-50.

Montoya Juárez, Jesús. “Aira y los airianos: literatura argentina y cultura masiva desde los años noventa”. Entre lo local y lo global: la literatura latinoamericana en el cambio de siglo. Jesús Montoya Juárez y Ángel Esteban, eds. Madrid: Iberoamericana; Frankfurt am Main: Vervuert, 2008. 51-76.

“César Aira, lo básico es la invención”, entrevista a César Aira. Revista Kafka 3 (Universidad de Salamanca-Kadmos 2004): 155-67.

“Las mil caras de César Aira”. Tonos: revista electrónica de estudios filológicos 9 (2005). Junio 2005. <www.um.es/tonosdigital/znum9/estudios/aira.htm>1 dic. 2010. "Ni apocalípticos ni integrados: medios audiovisuales en tres narradores del Sur de América”. Tecnoescritura: literatura y tecnología en América Latina. Revista Iberoamericana LXXIII/221 (oct.-dic. 2007): 887-902.

Realismos del simulacro: imagen, medios y tecnología en la narrativa del Río de la Plata. Tesis de doctorado. Universidad de Granada. Ángel Esteban, dir. Granada: Servicio de Publicaciones de la Universidad de Granada, 2008.

Noemí, Daniel. Leer la pobreza en América Latina: literatura y velocidad. Santiago: Cuarto Propio, 2004.

"Y después de lo post, ¿qué? (Realismos, vanguardias y mercado en la narrativa hispanoamericana del siglo XXI)”. Entre lo local y lo global: la literatura latinoamericana en el cambio de siglo. Jesús Montoya Juárez y Ángel Esteban, eds. Madrid: Iberoamericana; Frankfurt am Main: Vervuert, 2008. 83-98.

Revista Iberoamericana, Vol. LXXVII, Núms. 236-237, Julio-Diciembre 2011, 919-937 ISSN 0034-9631 (Impreso) 
O’Connor, Patrick. “César Aira’s Simple Lesbians: Passing la Prueba”. Latin American Review 54 (1999): 23-38.

Paz, Octavio. Apariencia desnuda. La obra de Marcel Duchamp. México: Era, 1978.

Pineda, Victoria. "La invención de la écfrasis". Homenaje a la profesora Carmen Pérez Romero. Cáceres: Universidad de Extremadura, 2005. 251-62.

Poster, Mark. "Postmodern Virtualities”. Media and Cultural Studies. Gigi Durham M. y D. Kellner, eds. Oxford-Malden: Blackwell, 2002. 611-25.

Prieto, Julio. "Vanguardia y mala literatura: de Macedonio a César Aira”. César Aira, une révolution, Tigre, (número hors série 2005). Michel Lafon, Cristina Breuil y Margarita Remon-Raillard, eds. Université Stendhal-Grenoble 3. 181-94.

Pulp Fiction. Dir. Quentin Tarantino. Miramax Films, 1994.

Remón Raillard, Margarita. César Aira o la literatura del continuo. Tesis de doctorado. Université Stendhal-Grenoble 3. Dir. Michel Lafon. 1999.

Richard, Nelly. "Latinoamérica y la posmodernidad”. Posmodernidad en la periferia, enfoques latinoamericanos de la nueva teoría cultural. Hermann Herlinghaus y Walter Mignolo, comps. Berlín: Astrid Larger Verlag, 1994. 210-22.

"Latinoamérica y la postmodernidad: la crisis de los originales y la revancha de la copia”. La estratificación de los márgenes. Santiago de Chile: Francisco Zegers, 1989. 49-58.

Ryan, Marie Laurie. “Cyberspace, Virtuality and the Text”. Cyberspace, Textuality, Computer Technology and Literary Theory. M. Ryan, ed. Bloomington: Indiana UP, 1999. 78-107.

Santos, Lidia. Kitsch tropical: los medios en la literatura y el arte en América Latina. Madrid: Iberoamericana; Frankfurt am Main: Vervuert, 2004.

Sarlo, Beatriz. Escenas de la vida posmoderna: Intelectuales, arte y videocultura en la Argentina. Buenos Aires: Ariel, 1994.

Tan de repente. Dir. y guión Diego Lehrman. Transeuropa Video Entertainment, 2003. Virilio, Paul. Cibermundo: ¿una política suicida? Santiago: Dolmen, 1997.

Revista Iberoamericana, Vol. LXXVII, Núms. 236-237, Julio-Diciembre 2011, $919-937$
ISSN 2154-4794 (Electrónico) 
